\title{
LEG DISPOSITION IN THE BRACHYURAN MEGALOPA WHEN SWIMMING
}

\author{
By D. Atkins, D.Sc.
}

(Text-figs. I and 2)

As long ago as I852 Dana carefully described and figured the position of the legs of certain megalopae whilst swimming. Later writers having apparently overlooked his observations, his remarks are worth quoting in full, remembering that he is writing of five pairs of legs: 'In the genera Monolepis, Marestia and Cyllene, and probably also in Tribola, ${ }^{\star}$ the posterior legs are capable of overlying the posterior angle of the carapax, and there is a corresponding depression in this surface, which depression is sometimes abrupt and channellike. The penult pair of legs also admits of being thrown forward over the border of the carapax, and extends above the base of the eyes, so that the tarsus hangs down in front. The second and third pairs fold up and partially overlap the sides of the carapax, beneath the fourth or penult pair, or, as is sometimes seen, the third pair is thrown forward like the fourth. A species very near Megalopa mutica, abundant near the Cape of Good Hope is figured on plate $3 \mathrm{I}$, with the legs in the position they had while the animal was swimming. This position is not often observed, since the animal when disturbed, is almost sure to swim with the legs extended; and the hinder legs are mostly like the others in form and habit. On the same plate, this position is shown for another species from the Sooloo Sea; in the former, the surface of the carapax is simply a little depressed or concave for the folded posterior legs (genus Marestia) while in the latter (genus Monolepis), as shown in figure $5 b$, there is an abrupt channel' (Dana, I852b, pp. 485-6, pl. 3I, figs. $2 a, 5 a)$.

Unaware of Dana's work I have recently made observations on the swimming of the megalopae of a number of species of crabs at Plymouth.

The brachyuran megalopa when walking (e.g. Carcinides), or when clinging to an object (e.g. Macropodia), uses its legs as in the crab stage. When swimming, by means of the pleopods, with abdomen outstretched, two different methods of disposing of the legs have been observed. In the more spectacular method, found in all but three of the species examined at Plymouth, the legs are packed away in a curious manner so that the body is compact and the outline approximately rectangular in dorsal and ventral

* Megalopae respectively of Ocypode, Grapsids?, Lupa (Portunus) and Plagusia?, see Gurney, 1939, pp. II8, II9. 
view, but wider in front than behind because of the eyestalks. This arrangement of the legs when swimming is common to the following species: Portunus depurator, $P$. puber, $P$. arcuatus, $P$. pusillus, $P$. marmoreus, $P$. holsatus, Carcinides maenas, Portumnus latipes, Cancer pagurus, Atelecyclus septemdentatus, Pilumnus hirtellus, Pinnotheres pisum (but not P. pinnotheres) (Brachyrhyncha); Ebalia tuberosa, E. cranchii (Oxystomata); Maia squinado, Eurynome aspera, Hyas sp., and several species of Inachus and Macropodia (Oxyrhyncha). It is briefly that, while the chelipeds and first two pairs of walking legs are folded beneath the body, the third and fourth pairs are wrapped over the dorsum, the third being stretched out anteriorly (Figs. I and 2).

The chelipeds are carried on the ventral surface, bent upon themselves at the carpus, the chelae pointing posteriorly and touching in the mid-line of the thorax (Fig. 2B). The exact disposal of the chelipeds varies somewhat according to their length and size. In the megalofa of Carcinides there is a curiously large hook on the ischium of the cheliped, and when the chelipeds are folded for swimming the chela lies to the inner side of this (Fig. 2A). It appears to be present in most of the British Brachyrhyncha, although not in the Oxyrhyncha and Oxystomata megalopae (Lebour, 1928), and Lebour (1944, p. I3) noted in Portumnus latipes that these large hooks help in holding fast the food while the megalopa swims.

The proximal segments of the first and second walking legs are directed anteriorly and dorsally close to the side of the body, even slightly overlapping the dorsum in long-legged megalopae (Fig. IC), bent sharply at the carpus, the propodus and dactylus being on the ventral surface, lying close together and to the chelipeds (Fig. 2B).

The proximal segments of the third walking legs are curved round the side of the body on to the dorsum and the leg is stretched out anteriorly, fitting in a groove by the side of the gastric hump. The dactylus curves over the eye stalk and, according to the length of the leg, projects slightly beyond it, as in Eurynome aspera, Ebalia (Fig. IB); or is looped round it on to the ventral surface, the tip directed posteriorly, as in Hyas, Inachus, Macropodia (Fig. IC), with long slender legs. In Carcinides maenas the dactylus is sometimes stretched out straight and sometimes curved round the eye (Figs. IA, 2A) as it is also in Portunus spp.

The fourth walking legs, which are curved over the dorsum, are bent back upon themselves at the carpus, the ischium and merus being directed anteriorly and medially, the carpus and propodus posteriorly and outward and the dactylus posteriorly and inward, its tip reaching the base of the ischium. The tip projects slightly beyond the thorax, fitting into the angle between it and the abdomen. In Macropodia and Inachus the proximal ends of the carpi of the two sides touch or almost touch in the mid-dorsal line (Fig. IC), while there is a small space between them in Eurynome and a wider space in 

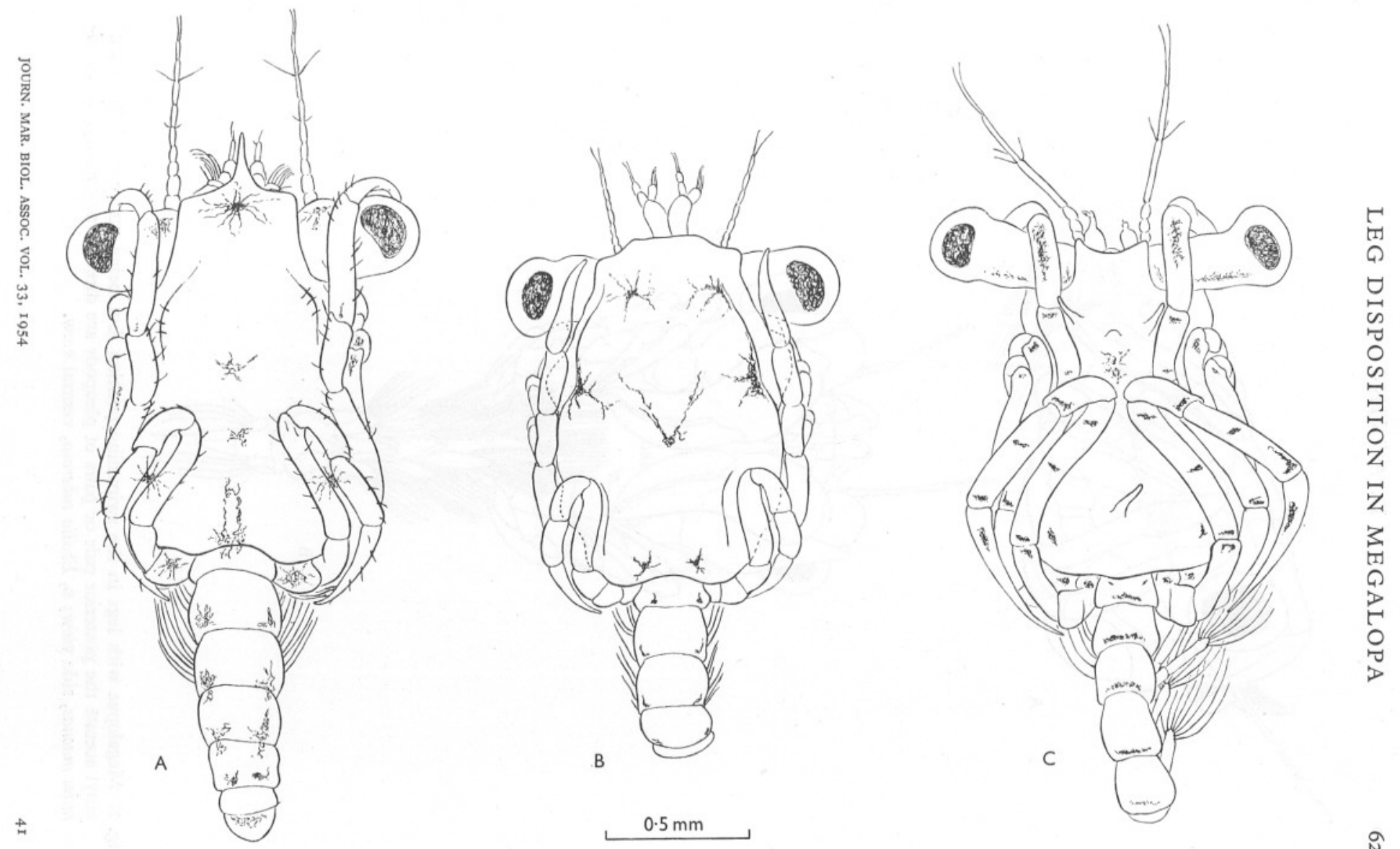

Fig. I. Megalopae with legs in the swimming position, dorsal view: drawn alive. A, Carcinides maenas; B, Ebalia tuberosa; c, Macropodia sp. 


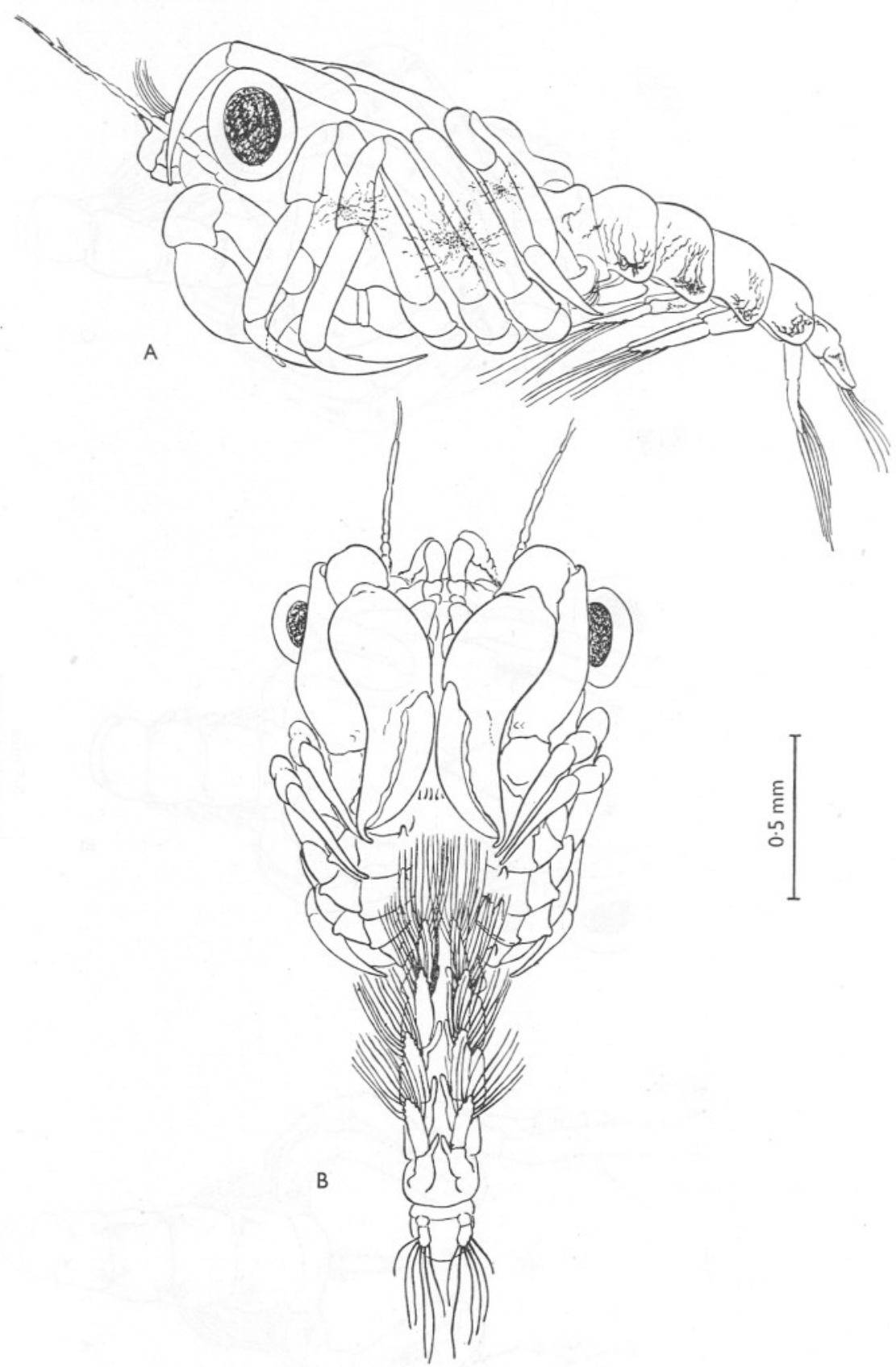

Fig. 2. Megalopae with legs in the swimming position, but being under the influence of ethyl acetate the posterior pair or pairs of pleopods are directed posteriorly. A, Carcinides maenas, side view; B, Ebalia tuberosa, ventral view. 
Portunus, Carcinides and Ebalia. In Ebalia the body is thick and the fourth walking legs fit into depressions, while the third are more to the side than in most megalopae and curve round the dorsal hump (Fig. IB).

The arrangement of the legs is most easily seen in Macropodia and Inachus in which the body is nearly transparent and little pigmented, and the legs banded with dark pigment, so that the third and fourth walking legs are conspicuous on the dorsum. Then, perhaps owing to the length of the legs or conditions of captivity, these megalopae and those of Eurynome, arrange their legs slowly enough for the eyes to follow the movement. Also some of them were observed frequently to rest on the bottom after a swim with their legs in the swimming position.

It was at first difficult to see the manner in which the Carcinides megalopa carried its legs, for the legs are transparent and almost colourless. When the third and fourth walking legs are folded over the back they are practically invisible. Moreover, these megalopae are particularly rapid in their movements, folding the legs and jumping into their swim in an instant. The forward and upward leap is coincident with the sudden straightening of the abdomen from the bent position beneath the thorax.

Unlike Williamson's (1903, p. I58) observation that in the megalopa of Carcinides the abdomen remains extended and is never tucked in under the thorax, the few specimens seen walked with it curved beneath the thorax; when molested the animal curled up with the legs in the swimming position and the abdomen tucked under the thorax, taking up the position shown in Crane's figure 2 (1940) of Ocypode albicans. Several other species behaved in the same manner (see also Kemp, I915, p. 219): it was recorded of Calappa marmorata (Oxystomata) by Smith (I880, p. 266), but with the difference that chelipeds and all legs were folded very compactly beneath the carapace. This behaviour possibly varies with age, the abdomen being more apt to be tucked under the body as the moult to the crab stage approaches. The megalopae of Macropodia and Inachus, on the other hand, were rarely seen with the abdomen bent under, even during the day or two preceding the moult, although they momentarily flexed it. This habitual extension of the abdomen may be because these megalopae rarely seem to walk, but will cling to objects with all legs.

That the described arrangement of the legs when swimming is probably common to many other megalopae than those observed at Plymouth would seem to be indicated by many published figures of this post-larval stage, the proximal segments of the third and fourth walking legs projecting well beyond the carapace, either posteriorly or laterally (Connolly, I923, fig. II; I925, fig. 6; Hart, I935, figs. $2 \mathrm{~A},{ }_{3} \mathrm{~K}, 6 \mathrm{~A}, 7 \mathrm{H}$; Lebour, 1928 , many figures) and some even showing the fourth pair of legs folded over the dorsum, for instance Connolly's figure II of the megalopa of Cancer amoenus and Lebour's figure 8, pl. xi, of Xantho incisus. In some instances, no doubt, the protrusion of the 
proximal segments of the last two legs, as shown in the figures mentioned above, is partly due to the preservative, especially if formalin had been used, but Dr Lebour informs me that her figures were of living or moribund specimens so that the proximal segments of the last two pairs of legs would be in the normal position.

This comparative freedom of the last two pairs of legs from the carapace as compared with the other legs, which allows of their being wrapped over the dorsum in the swimming megalopa, is more pronounced in some megalopae and crabs than in others. In certain species the last two pairs of legs, which are said to arise dorsally, have a specialized function if not specialized formation, and their freedom of movement is utilized to hold objects over the carapace. For instance in the Dorippidae (Oxystomata), Ethusa investigatoris (Menon, 1937), Dorippe dorsipes and D. facchino (Hornell, I922, p. 932) have the claws of the last two pairs of legs modified so that they can hold shells, etc., on their backs, and this habit may even be exhibited by the megalopa (Menon, I937, p. 42). The last two pairs of legs of the first and second young crab stages of Pilumnus hirtellus have great freedom of movement and can be stretched over the dorsum when clasping objects. The last pair, moreover, can be stretched directly backward and the young crabs frequently stand on their heads, ventral surface uppermost, supported on the front and the tips of the posteriorly and dorsally stretched last pair of legs. Dressing of the dorsum by the last pair of legs was not observed; it may be that debris collects on it because young crabs so frequently lie on their backs.

Among the megalopae observed at Plymouth three exceptions occurred to the usual method of disposing of the legs. In these, all the legs including the chelipeds were bent up under the body while swimming, as described by Gurney (1903, p. 464) for Corystes cassivelaunus. In addition to Corystes, Thia polita and Pinnotheres pinnotheres (=veterum) swam in this manner. These megalopae appeared to swim less rapidly than those which were more finely stream-lined. They were obtained by moulting from zoeae in captivity, but seemed healthy enough; they were watched swimming a number of times, and it would appear to be their normal method, although it would have been more satisfactory if the megalopae had been taken direct from the plankton. As Dana (1852b, p. 486) has cautioned, megalopae may need to be watched for some time before they show their characteristic method of swimming. Those which normally swim with the third and fourth legs over the dorsum may on occasion swim without packing the legs tightly away, but holding them loosely bent about the middle, with the chelipeds in a loose bow, tips close together in mid-line. They then swim slowly by comparison with their rapid movement when the legs are compactly stowed away.

A reason for the legs being held close to the body, the third and fourth folded over the dorsum, is no doubt that the stream-line effect offers less resistance to movement in water; moreover, the arrangement may have some- 
thing to do with improved balance whilst swimming. If it allowed of increased speed in swimming it would be an advantage in escaping from danger. Although megalopae are known to eat fast-moving larvae, including zoeae and other megalopae (Lebour, 1927, p. 807; 1928, p. 500), it is not known if they actively hunt them. Incidentally the removal of the last two pairs of legs on to the dorsum prevents any possibility of their interfering with the action of the anterior pleopods, the swimming setae of which extend well forward on to the thorax at the beginning of the effective stroke, which is backward with the plumose setae spread out fanwise. Less effective is the arrangement in which all legs are bent beneath the body, as can be assessed by watching the swimming of megalopae with the two different arrangements of the legs.

The three species of megalopae which swim with all legs folded beneath the body possibly have a pelagic existence of short duration. The megalopa of Corystes cassivelaunus is very crab-like and, as noted by Gurney (I903, pp. 463-4), has most of the characteristics and habits of the adult, burrowing into fine sand. According to him it appears not to be a pelagic form properly speaking, and was only once obtained in the tow-net, and then within a fathom or so of the bottom, in deep water. Very occasionally the megalopae have been taken in swarms at the surface (Russell, I927, p. 602): as the zoeae apparently have a preference for the surface layers (Russell, I927, p. 602) it is possible that the swarms of megalopae had not long moulted into that stage. The megalopa of Thia polita (which incidentally has rather short legs) if provided with muddy gravel, on which the adult is taken, soon backs beneath it: this megalopa also may possibly have a short swimming stage. Pinnotheres pinnotheres possibly enters its host (Ascidia mentula at Plymouth) in the megalopa stage, for it is of a good size with a carapace length of $0.96 \mathrm{~mm}$. and width of $0.8 \mathrm{~mm}$.; the megalopae of Pinnixa faba (Pinnotheridae) are known to do so (Wells, I940). These megalopae once in the host would feed after the manner of the adult and would be in a protected position. The smaller megalopa of $P$. pisum, with carapace length of $0.69 \mathrm{~mm}$. and width of $0.56 \mathrm{~mm}$. swims with the third and fourth walking legs over the dorsum and because of its small size it is doubtful whether this species enters the mollusc host in the megalopa stage; the risk of its being smothered in mucus and expelled may be too great.

\section{Previous References to the Disposition of the Legs in Megalopae}

The megalopae of crabs occurring at Plymouth are of no great size. With the outstanding exception of Corystes cassivelaunus, with carapace length $3.36-3.6 \mathrm{~mm}$ and width $3.1-3.24 \mathrm{~mm}$, the largest Plymouth megalopa, that of Atelecyclus septemdentatus, has a carapace length of $2 \cdot 7 \mathrm{~mm}$. Although a few references to the position of the legs whilst swimming of megalopae of this size occur (Hyman, I920, p. 497; 1922, p. 455; Lebour, 1927, p. 807), they are 
not detailed, merely mentioning that the legs are folded against the body. They do not describe the peculiar posture noted in this paper. Hyman (I920, p. 497), however, mentioned that the last pair of legs in Uca (Gelasimus) are carried folded over the back and kept in that position even when clinging or walking.

The only account of the peculiar posture as occurring during swimming is that of Dana $(1852 a, b)$ already quoted (see p. 627). He observed it of megalopae of three genera, and of carapace length 3.3-II.0 mm. In addition several detailed descriptions occur of the complicated folding of the legs and of the grooving of the sides of the body and of the carapace posterio-laterally for the reception of the legs, and of the thorax for the repose of the abdomen, in a group of relatively gigantic megalopae, with carapace length $4 \cdot 0-9 \cdot 4 \mathrm{~mm}$, with thick hard cuticle, some of which belong to the Ocypodidae (Say, I8I7; Smith, I873; Kemp, I915; Miyake, I939, pp. I93-5, as a crab; Crane, I940; Edmonson, 1949). Most of these descriptions are of museum material, for curiously enough these large megalopae appear frequently to retain their legs folded against the body after death. Except for Dana, who actually observed them swimming, their peculiar characteristics have been considered as adapting them for life on sandy shores where certain of them have been taken, and some are known to moult into the first crab stage (Say, I8I7, p. I58; Smith, I873; I880, p. 255; Kemp, I9I5, p. 219; Edmonson, I949, p. 235), and where the adults live (Rathbun, I9I8, pp. 369, 372, 374). Such are rotund, have thick hard cuticle and the body so grooved for the reception of the legs and abdomen that they may be rolled about like tiny balls without appreciable injury (Crane, I940, pp. 66, 8I ; Edmonson, I949, p. 235). It may be recalled here that the megalopa of Ebalia, although tiny with a carapace length of about $\mathrm{I} \cdot 2 \mathrm{~mm}$, is also rotund and has marked depressions for the reception of the last pair of legs (p. 63I): the adult crabs occur in sand. It appears to me that in all probability the stream-lining of the body was originally an adaptation for swimming, for these large megalopae have the pleopods fully developed and a number have been taken in the open sea (Dana, I852a; I852b; Smith, I880, p. 255; Crane, I940, p. 8I; Edmonson, I949, p. 243). Moreover, the posture is common to many megalopae the adults of which do not inhabit sandy beaches, and grooving of the body for the reception of the legs has been described in a megalopa of Plagusia of carapace length $4.6 \mathrm{~mm}$ (Rathbun, I924; Boone, I927, p. 27I ; Crane, I940, p. 70) the adults of which live among rocks awash at high tide and on drift timber in the open sea (Rathbun, I9I8, p. 332). No doubt the grooving of the body for the reception of the legs when swimming is more apparent in large megalopae with thick cuticle than in those with thin cuticle or of small size.

This work was made possible by the kindness of the Board of Studies in Zoology of London University in granting me the use of the London 
University Table at the Laboratory of the Marine Biological Association at Plymouth.

I was unable to obtain on loan the volume of plates of Dana's Crustacea U.S. Navy $(1852 b)$ and am indebted to Dr J. Morton for kindly making sketches from pl. 3I of two megalopae in the swimming attitude.

\section{SUMMARY}

Many brachyuran megalopae swim with the legs disposed in a curious manner. The chelipeds and first two pairs of walking legs are folded tightly beneath the body, while the two posterior pairs are wrapped over the dorsum, the third pair being stretched out anteriorly, the dactylus, according to its length, touching or being looped round the eye-stalk. It is suggested that this posture gives stream-lining to the megalopa and improves its swimming. The described arrangement has been observed in all but three of some twenty-five species occurring at Plymouth.

In the three exceptions, Corystes cassivelaunus, Thia polita and Pinnotheres pinnotheres (=veterum), all legs are carried folded beneath the body.

Reference is made to previous descriptions of the folding of the legs in the brachyuran megalopa.

\section{REFERENCES}

Boone, L., I927. The littoral crustacean fauna of the Galapagos Islands. Part I Brachyura. Zoologica, N.Y., Vol. 8, pp. 127-288.

Connolly, C. J., I923. The larval stages and megalops of Cancer amoenus (Herbst.). Contr. Canad. Biol., N.S., Vol. I, pp. 337-52.

- 1925. The larval stages and megalops of Rhithropanopeus harrisi (Gould). Contr. Canad. Biol., Vol. 2, pp. 327-34.

CRANE, J., I940. On the post-embryonic development of brachyuran crabs of the Genus Ocypode. Zoologica, N.Y., Vol. 25, pp. 65-82.

DANA, J. D., I852 $a$. Conspectus of the Crustacea of the exploring expedition under Capt. Wilkes, U.S.N. Paguridea, continued, and subtribe Megalopidea. Proc. Acad. nat. Sci. Philadelphia, Vol. 6, pp. 6-1o.

- $1852 b$. Crustacea. U.S. Exploring Expedition during the years $1838-42$ under the Command of C. Wilkes, U.S.N., Vol. I3, pt. I.

Edmonson, C. H., I949. Some brachyuran megalopa. Occ. Pap. Bishop Mus., Vol. I9, pp. 233-46.

Gurney, R., I903. The metamorphosis of Corystes cassivelaunus (Pennant). Quart. $\mathcal{F}$. micr. Sci., Vol. 46, pp. 46I-78.

- 1939. Bibliography of the larvae of decapod Crustacea. Ray Soc. Publ., Vol. I25.

— I942. Larvae of decapod Crustacea. Ray Soc. Publ., Vol. I29.

HART, J. F. L., I935. The larval development of British Columbia Brachyura-I, Xanthidae, Pinnotheridae (in part) and Grapsidae. Canad. F. Res., Vol. I2, pp. 4II-32.

HoRNELl, J., I922. Some commensals of Indian alcyonarians and crabs. F. Bombay nat. Hist. Soc., Vol. 28, pp. 926-36. 
Hyman, O. W., I920. The development of Gelassimus after hatching. F. Morph., Vol. 33 (2), pp. 485-50I.

- 1922. Adventures in the life of a fiddler crab. Rep. Smithson. Instn, I920 (I922), pp. 443-60.

Kemp, S., I915. Fauna of the Chilka Lake: Crustacea Decapoda. Mem. Ind. Mus., Vol. 5, pp. 199-325.

Lebour, M. V., I927. Studies of the Plymouth Brachyura. I. F. Mar. biol. Ass., U.K., Vol. I4, pp. 795-821.

— 1928. The larval stages of the Plymouth Brachyura. Proc. zool Soc. Lond., I928, pp. 473-560.

- 1944. The larval stages of Portumnus (Crustacea Brachyura) with notes on some other genera. F. Mar. biol. Ass., U.K., Vol. 26, pp. 7-15.

Menon, M. K., I937. Decapod larvae from the Madras plankton. Bull. Madras Govt Mus., (nat. hist.) N.S., Vol. 3, No. 5.

Mryake, S., I939. Notes on Crustacea Brachyura collected by Professor Teiso Esaki's Micronesia Expeditions 1937-1938. Rec. oceanogr. Wks fap., Vol. Io, pp. I68-247.

Rathbun, M. J., I9I8. The grapsoid crabs of America. Bull. U.S. nat. Mus., No. 97.

— I924. Brachyuran crabs collected by the Williams Galapagos expedition, I923. Zoologica, N.Y., Vol. 5, pp. 153-9.

RUSSELL, F. S., I927. The vertical distribution of marine macroplankton. V. The distribution of animals caught in the ring-trawl in the daytime in the Plymouth area. F. Mar. biol. Ass., U.K., Vol. I4, pp. 557-608.

SAY, T., I817. An account of the Crustacea of the United States. F. Acad. nat. Sci. Philadelphia, Vol. I, pp. I55-69.

Smith, S. I., I873. The megalops stage of Ocypoda. Amer. F. Sci., Vol. 6 (3), no. I. I880. Occasional occurrence of tropical and sub-tropical species of decapod Crustacea on the coast of New England. Trans. Conn. Acad. Arts Sci., Vol. 4, pp. 254-67.

WeLLS, W. W., 1940. Ecological studies on the pinnotherid crabs of Puget Sound. Univ. Wash. Publ. Oceanogr., Vol. 2, pp. 19-50.

Williamson, H. C., I903. On the larval and early young stages, and rate of growth of the shore-crab (Carcinus maenas Leach.). Rep. Fish. Bd Scot., Ann. 2I (I902), pp. 136-79. 